\title{
The Role of Medical Sciences to Save Lives of Mankind from Communicable and Non-Communicable Diseases Including Current COVID-19 Pandemic
}

\author{
Ahsan Ali Siddiqui*, MD, MSPH, UK \\ Consultant Public Health, Quality Management \& Patient Safety Department, General Directorate of Health, Saudi Arabia
}

\begin{abstract}
Background and Objective: The main Aim of this article is to show the Importance and role of medical sciences to save lives of mankind from Communicable and Non-Communicable Diseases including current COVID-19 Pandemic. This Article includes various Articles references discussing the Diseases such as Hypertension, Diabetes, Cancer, Tuberculosis, Avian Flu and COVID-19.
\end{abstract}

Methods: The Author of this article has randomly selected 15 Articles from PUBMED, Other Different Medical Sciences Journals with the word using "medical sciences to save lives of mankind". The Author relies on Conceptual Literature Review for the Methodology of this article. Where the groups of Articles are reviewed and analyzed to find out the answer of the Question "Study favors or Ignores role of medical sciences to save lives of mankind from Communicable and NonCommunicable Diseases including current COVID-19 Pandemic". The Table 1 is created to Analyze the 15 randomly selected Articles and the results has been presented By SPSS software diagrammatic presentation.

Results: Author of this Article has used SPSS 19 Software to present the results. First SPSS Diagram shows that All selected 15 Articles favors the Importance of role of medical sciences to save lives of mankind from Communicable and NonCommunicable Diseases including current COVID-19. The Second SPSS Diagram shows that 15 Articles agreed 100\% for the Importance of role of medical sciences to save lives of mankind from Communicable and Non-Communicable Diseases including current COVID-19.

Conclusion: This Article teaches us the lesson that Technology in Medical Sciences and Inventions, Discovery of new Medicines and Surgical Instruments are Blessings for Mankind. Latest Technologies such as MRI Scans, CT Scans, Chemotherapy, Radiotherapy, Nuclear Technology, X rays/ Ultrasound, Latest Laparoscopic surgery, Endoscopy, Angioplasty others are treating more ill patients than ever before. But more Medical research is needed to find the Treatment for COVID-19 Pandemic, Ebola, MERS, Avian Influenza, Swine Flu and other Viral diseases. Urgent research institutes needed to build up for the discovery of new Vaccines when needed in times of COVID-19 Pandemic.

KEYWORDS: COVID-19; Chloroquine; MERS; Morbidity; Remdesivir; SARS-CoV-2; Importing; Iran; Outbreaks; Spreading; Acute respiratory distress syndrome; Antiviral; WHO list of Tuberculosis; Preventive measures against tuberculosis; Sleep apnea; Hypertensive patients; duration of hypertension; Neurological Symptoms; Hypertension; Blood pressure levels; Vitamin A deficiency; Maternal mortality; Child mortality

Quick Response Code:

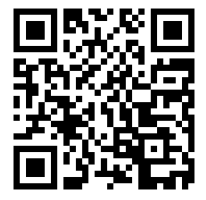

Address for correspondence: Ahsan Ali Siddiqui, MD, MSPH, UK, Consultant Public Health, Quality Management \& Patient Safety Department, General Directorate of Health, Saudi Arabia

Received: June 09, 2020 Published: June 25, 2020

How to cite this article: Ahsan Ali Siddiqui, MD, MSPH, UK. The Role of Medical Sciences to Save Lives of Mankind from Communicable and Non-Communicable Diseases Including Current COVID-19 Pandemic. 2020 - 2(3) OAJBS.ID.000184. DOI: 10.38125/OAJBS.000184 


\section{INTRODUCTION}

Despite the urgent need to find a Serap [1] effective antiviral treatment for COVID-19 through randomized controlled studies certain agents are being used all over the world based on either in-vitro or extrapolated evidence or observational studies. Nitazoxanide and ivermectin were also included in this review as they have recently been reported to have an activity against SARSCoV-2 in vitro and are licensed for Serap [1] the treatment of some other human infections.
Current Pandemic of COVID-19 has taught Siddiqui [2] us that we in the twenty first century is not ready to provide health care to vulnerable community such as elders, children and sick people with chronic illness. Such vulnerable people with bad health and low socio-economic status are more prone to get effected by COVID-19 novel corona virus. More serious work needed to be done by Global health agencies and world organizations such as WHO, CDC, UN, UNESCO, UNHCR others. Governments and health departments has to make useful health policies to implement in deadlines with serious Siddiqui [2] accountability to fight against any Epidemic or Pandemic (Figure 1).

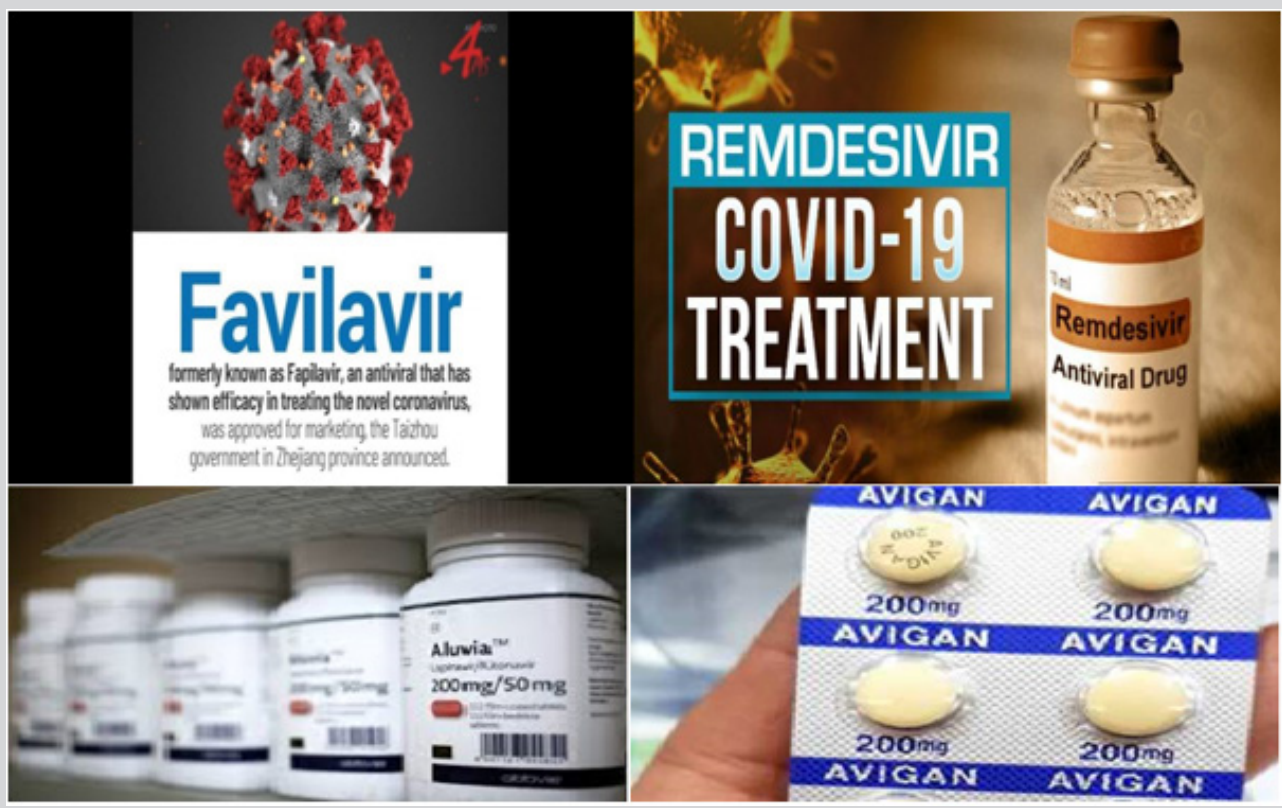

Figure 1: [27].

Since the outbreak of COVID-19 Jeroen [3] chloroquine has been mentioned as a possible treatment. In vitro studies have shown anti-viral activity of chloroquine against SARS-CoV-2. Recently the Dutch National Institute for Public Health and the Environment published treatment options for antiviral treatment for COVID-19 where chloroquine was suggested as first choice for off-label treatment beside remdesivir, lopinavir/ritonavir. In this commentary we provide a background and history of chloroquine the evidence for antiviral efficacy of chloroquine and the arguments for off-label use of chloroquine Jeroen [3] in COVID-19.

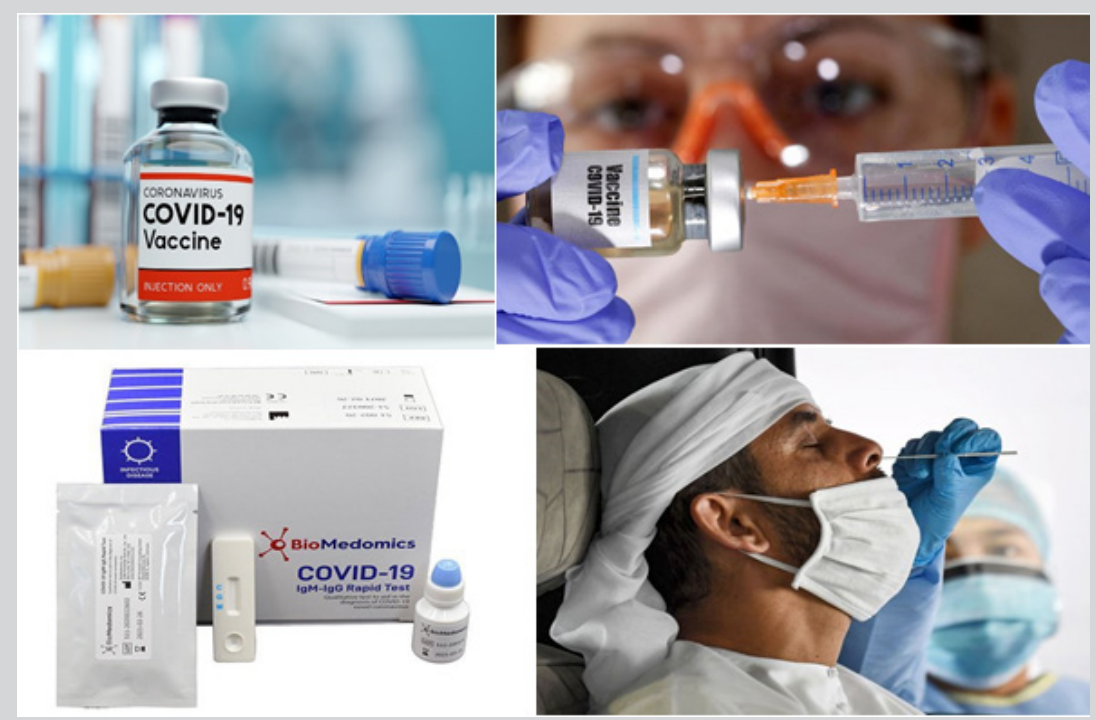

Figure 2: [27]. 
Upon reviewing the 8 News Articles Siddiqui AA [4] specially to collect the evidence only two articles provide the picture and documented evidence that may be accidentally in the Wuhan laboratory the studied novel corona virus got out of laboratory. By looking at the results of the data table data analysis and diagrammatic presentation $25 \%$ of the News articles Siddiqui AA [4] provides some evidence and $75 \%$ of the news articles did not provide any evidence. The evidence we are looking at that Wuhan laboratory is clearly responsible for accidentally leaking the novel corona virus COVID-19 in the community (Figure 2).

Our study predicted that Reena [5] among male and female cancer patients on chemotherapy more than half of males were found to have febrile neutropenia while less females had febrile neutropenia. A total of 256 patients on Reena [5] chemotherapy was included in this study after getting informed consent. Patients having co morbid conditions and neurologic impairment were excluded from this study. This can prevent secondary impairment in cancer patients Reena [5] already undergoing chemotherapy.

All patients were initially treated Klaassen [6] with pelvic radiotherapy arm A, 2,250 rad in ten fractions: and arms B and C, 4,500 rad in 20 fractions. Entry to arm $C$ was discontinued early because of toxicity. In a multifactor analysis using proportional hazards models, no significant difference in survival was observed although there was a marginally significant difference in diseasefree survival $(\mathrm{P}=.015)$ with arm $\mathrm{B}$ being superior to arm A. Stage (P less than .0001), grade (P less than .0001), and histology (P less than .008) were predictors of survival in the multifactor analysis. Five-year survival rates are $62 \%$ for arm A, 61\% for arm B, and $66 \%$ for arm C. Median duration of follow-up is 8 years. Long-term complications of radiotherapy were seen in 19 patients on arm
A, 11 on arm B, and 11 on arm C. Four patients who had received Klaassen [6] melphalan developed either a myelodysplastic syndrome or acute leukemia.

This article describes a model for TB control program which contains the essential components of a successful TB control program and some important strategies for TB prevention and control. And the Essay also discuss the factors responsible for the acceleration of the TB in Pakistan and the new changes needed in prevention and improvement of TB control program. The incentive based Hamidah [7] active case finding program costed USD 223 per patient treated. In contrast the center based non-incentive arm was $23.4 \%$ cheaper costing USD 171 per patient treated. Both screening strategies appear to be cost-effective in an urban Pakistan context. Incentive driven active case findings of TB in the private sector costs less and averts more DALYs per health seeker than passive case finding Hamidah [7] when both alternatives are compared to a common baseline situation of no screening.

In this essay I have discussed the dangers and the harmful effects done by the Avian flu and the spread, distribution of the Disease as an Epidemic across the region. I would like to add that No- I don't think that enough work is done to handle this great threat of Avian flu. Avian flu is affecting the poultry animals' world over since first outbreak in 1997 in Hong Kong. Lack of effective vaccine poor knowledge about treatment and with scarcity of public health measures in developing countries are major causes of concern. The real threat of impending pandemic can be avoided only if we act immediately on the basis of currently available source of information and apply scientific knowledge rationally for containment and prevention of bird flu and treat human cases promptly (Figure 3).

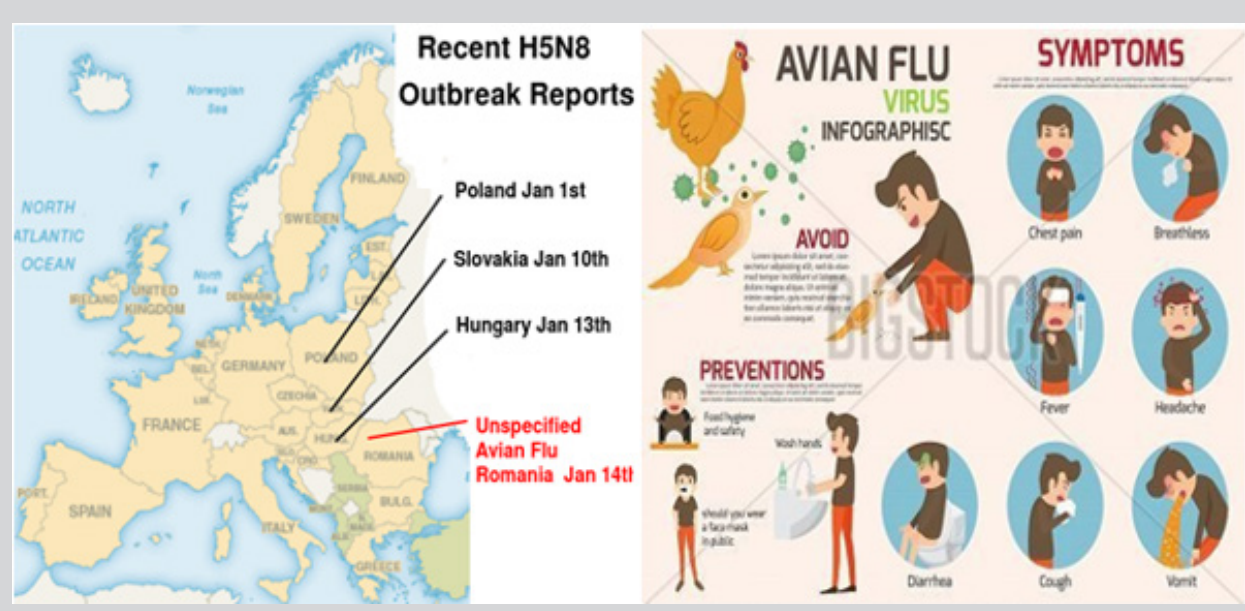

Figure 3: [34].

The study results revealed Anwar [8] a positive association between longer duration of hypertension and presence of sleep apnea only before controlling for the potential confounding effects of age. A cross-sectional study was carried out on a total of 300 conveniently sampled patients aged 18 in OPD in the Hospital. The results show the relationship between longer duration of Hypertension and High prevalence of sleep Apnea. though after controlling for the confounding effects of Natasha [9] age through stratification this association no longer persisted.

\section{METHODS}

The Author of this article has randomly selected 15 Articles from PUBMED, Other Different Medical Sciences Journals with the word using "medical sciences to save lives of mankind". The Author relies on Conceptual Literature Review for the Methodology of this article. Where the groups of Articles are reviewed and analyzed to find out the answer of the Question "Study favors or Ignores role of medical sciences to save lives of mankind from Communicable and Non-Communicable Diseases including current COVID-19 Pandemic". The Table 1 is created to Analyze the 15 randomly selected Articles and the results has been presented By SPSS software diagrammatic presentation. 
Table 1: 15 Selected articles to show the importance of role of medical sciences to save lives of mankind from communicable and non-communicable diseases including current COVID-19 Pandemic.

\begin{tabular}{|c|c|c|c|c|}
\hline S.NO & $\begin{array}{c}\text { Complete Reference of } \\
\text { the Articles selected } \\
\text { for study }\end{array}$ & $\begin{array}{l}\text { Study Favours the } \\
\text { Importance of Urgent } \\
\text { Recent Management } \\
\text { and Treatment, Vaccine } \\
\text { for the COVID-19 Novel } \\
\text { Corona Virus-YES }\end{array}$ & $\begin{array}{l}\text { Study Ignores the Importance } \\
\text { of Role of Medical Sciences } \\
\text { to Save Lives of Mankind } \\
\text { from Communicable and } \\
\text { Non-Communicable Diseases } \\
\text { Including Current COVID-19-No }\end{array}$ & $\begin{array}{c}\text { Percentages } \% \text { of Articles } \\
\text { agreed the Importance of } \\
\text { Urgent Recent Management } \\
\text { and Treatment, Vaccine for } \\
\text { the COVID-19 Novel Corona } \\
\text { Virus }\end{array}$ \\
\hline 1 & $\begin{array}{l}\text { Ahsan Ali Siddiqui (2020) } \\
\text { The epidemiology of } \\
\text { COVID-19 novel corona } \\
\text { virus to possibly control the } \\
\text { disease and other factors } \\
\text { relating to health around the } \\
\text { World 2(2): } 330-337 .\end{array}$ & YES & ------- & $100 \%$ \\
\hline 2 & $\begin{array}{l}\text { Ahsan Ali Siddiqui (2020) } \\
\text { True or not? Chinese } \\
\text { government quotes WHO } \\
\text { Chief statement "that there } \\
\text { is no Evidence that the } \\
\text { New Coronavirus Novel } \\
\text { COVID } 19 \text { was Produced } \\
\text { in the Laboratory" But US } \\
\text { Government Says, "that the } \\
\text { Coronavirus Originated } \\
\text { from a Laboratory in } \\
\text { China despite the Lack of } \\
\text { Evidence". Biomed J Sci \& } \\
\text { Tech Res 27(5). }\end{array}$ & YES & ------- & $100 \%$ \\
\hline 3 & $\begin{array}{c}\text { Serap Y, Serhat Ü (2020) } \\
\text { Antiviral treatment of } \\
\text { COVID-19. Turkish Journal } \\
\text { of Medical Sciences 50(SI-1): } \\
\text { 611-619. }\end{array}$ & YES & ------ & $100 \%$ \\
\hline 4 & $\begin{array}{l}\text { Jeroen C, Peter V (2020) } \\
\text { Chloroquine as a possible } \\
\text { treatment for COVID-19. } \\
\text { Nederlands Tijdschr } \\
\text { Geneeskd 164: D4936. }\end{array}$ & YES & ------- & $100 \%$ \\
\hline 5 & $\begin{array}{c}\text { Reena P, Ali J, Ahsan Ali } \\
\text { S, Nasir M (2018) Febrile } \\
\text { neutropenia in patients } \\
\text { receiving chemotherapy; } \\
\text { an observational study } \\
\text { highlighting its association } \\
\text { with hematological } \\
\text { parameters on gender basis. } \\
\text { Cancer Sci Res Open Access } \\
\text { 5(1): 1-5. }\end{array}$ & & YES & ------- \\
\hline 6 & $\begin{array}{c}\text { Reena K, Ahsan AS, } \\
\text { Khurram Z, Zubair T (2018) } \\
\text { Correlation of duration } \\
\text { of chemotherapy with } \\
\text { electrolytes in cancer } \\
\text { patients: a prospective study } \\
\text { assessing the relationship } \\
\text { with various electrolytes. } \\
\text { Cancer Sci Res Open Access } \\
\text { 5(2): 1-4. }\end{array}$ & & YES & ------ \\
\hline 7 & $\begin{array}{l}\text { A Siddiqui (2018) } \\
\text { Tuberculosis in adults in } \\
\text { Pakistan: Its epidemiology, } \\
\text { preventive measures and } \\
\text { current legislation. Journal } \\
\text { of American Academic } \\
\text { Research 6(3): 33-38. }\end{array}$ & YES & ------- & $100 \%$ \\
\hline
\end{tabular}




\begin{tabular}{|c|c|c|c|c|}
\hline 8 & $\begin{array}{c}\text { Ahsan Ali S (2018) The } \\
\text { global threat of bird (avian) } \\
\text { flu its treatment methods } \\
\text { and public health preventive } \\
\text { measures. SOJ Vet Sci } 4(3): \\
\text { 1-4. }\end{array}$ & YES & ------ & $100 \%$ \\
\hline 9 & $\begin{array}{c}\text { Anwar A, Fatima S, Zia } \\
\text { MK, Sohaib T, Ahsan AS, } \\
\text { et al. (2018) Sleep apnea } \\
\text { in hypertensive patients: } \\
\text { relationship with duration of } \\
\text { hypertension and the effect } \\
\text { of age. Palliat Med Care 5(4): } \\
\text { 1-4. }\end{array}$ & YES & ------ & $100 \%$ \\
\hline 10 & $\begin{array}{c}\text { Jamali Z, Siddiqui AA, } \\
\text { Jamali D, Nazim S (2018) } \\
\text { Correlation of early and late } \\
\text { cord clamping time with } \\
\text { hematological variables: an } \\
\text { observation study focusing } \\
\text { on the neonatal outcomes. } \\
\text { SOJ Gynecol Obstet Womens } \\
\text { Health 4(1): 1-5. }\end{array}$ & YES & ------ & $100 \%$ \\
\hline 11 & $\begin{array}{l}\text { Amna MB, Siddiqui AA, } \\
\text { Wajid Z, et al. (2018) } \\
\text { Presentations in patients of } \\
\text { chronic myeloid leukemia; } \\
\text { an observational study } \\
\text { focusing on the association } \\
\text { of hematological parameter } \\
\text { on gender. Cancer Sci Res } \\
\text { Open Access 5(1): } 1-5 \text {. }\end{array}$ & YES & ------ & $100 \%$ \\
\hline 12 & $\begin{array}{l}\text { Reena K, Ali SA, Zubair T, } \\
\text { Fatima S (2018) Levels } \\
\text { of electrolyte in cancer } \\
\text { patients; a prospective study } \\
\text { focusing on the Variations } \\
\text { before and after therapy. } \\
\text { Palliat Med Care 5(4): 1-4. }\end{array}$ & YES & ------- & $100 \%$ \\
\hline 13 & $\begin{array}{c}\text { Amna MB, Ahsan AS, } \\
\text { Shahzain H, Mir A (2018) } \\
\text { Characteristics of chronic } \\
\text { myeloid leukemia: an } \\
\text { observational study } \\
\text { highlighting the correlation } \\
\text { of age with hematological } \\
\text { parameters. Cancer Sci Res } \\
\text { Open Access 5(1): 1-4. }\end{array}$ & YES & ------- & $100 \%$ \\
\hline 14 & $\begin{array}{l}\text { Reena K, Ahsan AS, Shahzain } \\
\text { H (2018) Chemotherapy } \\
\text { in Different Cancers; } \\
\text { an Observational Study } \\
\text { Highlighting the Association } \\
\text { of Febrile Neutropenia } \\
\text { with Various Hematological } \\
\text { Parameters. Palliat Med Care } \\
\text { 5(3): 1-4. }\end{array}$ & YES & ------- & $100 \%$ \\
\hline 15 & $\begin{array}{c}\text { Adetunji H, Pinto L M, } \\
\text { Siddique A, Samuel S (2009) } \\
\text { Potential occupational } \\
\text { health risk from exposure } \\
\text { to nano-scale particles from } \\
\text { photocopiers - a pilot study. } \\
\text { Revue Internationale sur } \\
\text { l'Ingénierie des Risques } \\
\text { Industriels 2(1): 15-27 }\end{array}$ & YES & ------ & $100 \%$ \\
\hline
\end{tabular}


The present study predicted that Jamali [10] no correlation in either group existed between hemoglobin, hematocrit and bilirubin with increasing cord clamping time. Group 1 had clamping time of $45 \pm 7.92$ seconds and group 2 with clamping time of $118 \pm 33.26$ seconds. Hemoglobin was $13.29 \pm 1.33 \mathrm{mg} / \mathrm{dl}$ in group 1 and $13.43 \pm 1.06$ in group 2. Hematocrit was $40.87 \pm 3.78 \%$ and $41.36 \pm 3.02 \%$ in group 1 and 2 respectively. Bilirubin (mg/dl) was $9.15 \pm 5.77$ in group 1 while $13.14 \pm 10.14$ in group 2 . Anemia was present in $7.1 \%$ and $2.9 \%$ of infants in group 1 and respectively. High bilirubin was Jamali [10] seen in $4.1 \%$ and $19.4 \%$ infants of group 1 and 2 respectively.
The present study predicted Amna [11] that considerable difference did not exist in various hematological parameters of male and female CML patients. Chronic myeloid leukemia-CML Bradley [12] is a myeloproliferative disorder arising in the haemopoietic stem cell -HSC compartment. This disease is characterized by a reciprocal $t(9 ; 22)$ chromosomal translocation resulting in the formation of the Philadelphia chromosome containing the BCRABL1 gene. As such diagnosis and monitoring of disease involves detection of BCR-ABL1. It is the BCR-ABL1 protein in particular its constitutively active tyrosine kinase activity Bradley [12] that forges the pathogenesis of CML.

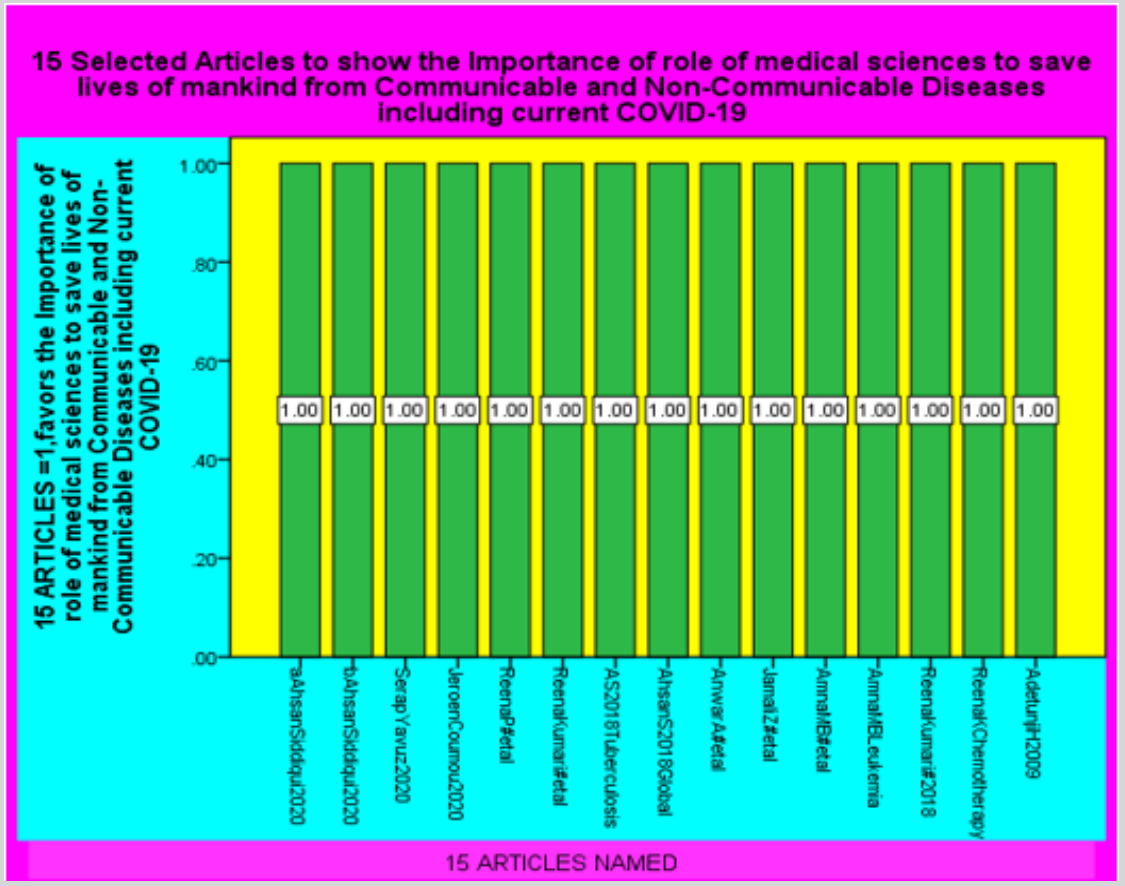

Figure 4

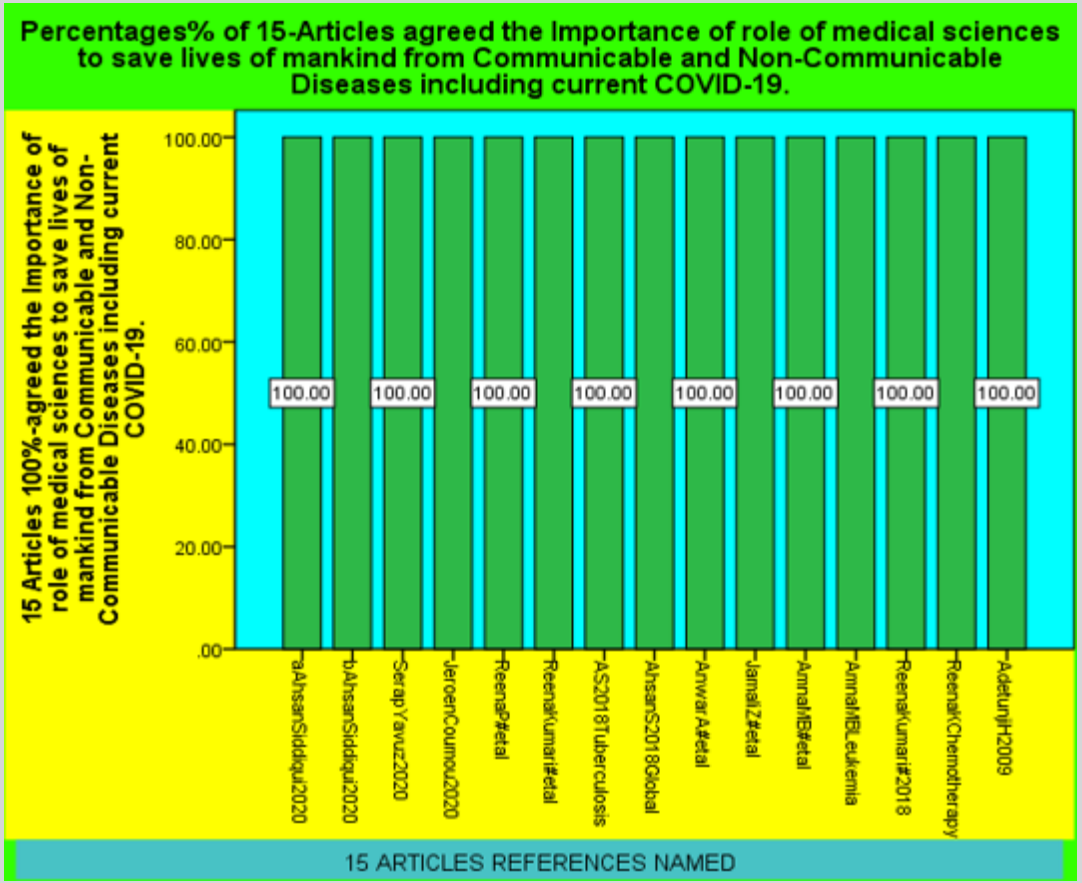

Figure 5 
This study demonstrates Khurram [13] that electrolyte imbalances are common during chemotherapy and monitoring should be done by medical oncologist. Paired t-test was used to assess the significance before and after treatment with $\mathrm{p}$ value of $<0.05$. The mechanisms responsible Bryan [14] for these particular electrolyte disturbances in the context of platinumbased chemotherapy treatment as well as to present the clinical manifestations and current management strategies for oncologists and primary care physicians since the latter are increasingly called on to provide care for cancer patients with medical comorbidities. Correct diagnosis and effective treatment Bryan [14] are essential to improved patient outcomes. Measure and statistical Analysis: IBM SPSS Software USA [15]; (Figure 4,5).

\section{RESULTS}

Author of this Article has used SPSS 19 Software to present the results. First SPSS Diagram shows that All selected 15 Articles favors the Importance of role of medical sciences to save lives of mankind from Communicable and Non-Communicable Diseases including current COVID-19. The Second SPSS Diagram shows that 15 Articles agreed $100 \%$ for the Importance of role of medical sciences to save lives of mankind from Communicable and NonCommunicable Diseases including current COVID-19.

A total of 100 patients were included in the study with mean age of $40.29 \pm 12.5$ years. Mean $\mathrm{Hb}$ was $9.65 \pm 7.0 \mathrm{~g} / \mathrm{dl}$ while Hct was $32.85 \pm 4.1 \%$. TLC was observed to be $228.7 \pm 152.3 \times 103$ cells $/ \mathrm{mm} 3$ though platelet count was $466.9 \pm 305.09 \times 103$ cells $/ \mathrm{mm} 3$. Moreover no correlation existed between age and various hematological parameters in these patients. Study predicted the median age of 40.29 years in patients suffering from chronic myeloid leukemia. Furthermore, no significant difference existed in hematological parameters and therefore no correlation observed with age in various hematological parameters in these patients.

Our study showed that significant difference exists in some of the hematological parameters including hemoglobin levels platelet count total leukocyte count neutrophil count monocyte count and absolute neutrophil count in patient treat with different chemotherapeutic drugs suffering from febrile neutropenia. Data was collected using non-probability convenient sampling technique after taking informed consent from 318 patients diagnosed as having cancer on histopathology undergoing treatment with chemotherapeutic agent and having neutropenia along with fever as a single oral temperature of $>38.3^{\circ} \mathrm{C}$.

\section{DISCUSSION}

This research design assignment Ahsan [16] has explored the methodological issues relating to the research question about how to improve the health infrastructure in Pakistan to reduce the Incidence of Tuberculosis. In a country like Ahsan [16] Pakistan controlling TB has become a challenge because of the lack of private sector involvement in a National Tuberculosis Control ProgramNTP. Therefore, collaboration is needed between public, private and government sectors in treating TB as well as in improving the Ahsan S [17] quality of the health care system.

Photocopier machines Kasi [15] are inevitable office equipment but they are also sources of air pollution. Research is essential to improve toner manufacturing processes and chemical composition of toners to reduce genotoxicity. Clean technologies are the need of the day to cut down on particulate matter and volatile organic compound emissions Kasi [18] from photocopiers. This work aimed to characterize Adetunji [19] and quantify the nanoscale particles emitted by a typical heavy-duty industrial photocopier and printer to assess the long-term effect of these particles on occupational health. The potential Adetunji [19] health risk related to toner particles is also explored.

Raised temperature was Momin [20] found to be significantly negatively correlated with total leukocyte count on day 3 only. Total leukocyte count Chmielewski [21] increases significantly in response to infection trauma inflammation and certain diseases. Factors affecting leukocyte count in healthy adults include sex hormonal milieu genetic inheritance stress level diet nutrition and lifestyle -e.g. tobacco-induced inflammatory changes chronic psychological stress etc. Numerous studies have reported that high but normal leukocyte counts at baseline predict increased cardiovascular and non-cardiovascular mortality in older adults. elderly people who tend to have high but normal leukocyte counts are at greater risk of cancer cardiovascular disease type 2 diabetes some other age-related conditions and they also have increased allcause mortality.

According to our study no Jamali [22] correlation exists between hemoglobin and hematocrit with cord clamping time, but weak positive correlation was observed between bilirubin levels with clamping time in seconds. Weak positive correlation $(\mathrm{p}=0.002$, $r=0.169$ ) existed between bilirubin levels with clamping time. No correlation was observed with cord clamping time and anemia low hematocrit or polycythemia (p-value 0.422 ), (p-value 0.058) and ( $p$-value 0.20 ) respectively while weak negative correlation $(\rho=-0.221)$ existed between high bilirubin levels in neonates with increasing cord Jamali [22] clamping time (p-value $<0.001$ ).

The study results Anwar [9] revealed vertigo and confusion were significantly associated with higher systolic blood pressure level whereas none of them were significantly associated with diastolic blood pressure level. More over, the binary logistic regression analysis showed that after controlling for the confounding effects of other neurological symptoms only confusion was significantly associated with systolic blood pressure level whereas none of the neurological symptoms studied Anwar [9] was significantly associated with diastolic blood pressure level.

The prevalence of smoking Adnan [23] chest pain vision problems fatigue and confusion were found to be different between both genders. The number Mackenbach [24] of diseases and conditions that are known to be caused by active smoking has now risen to over thirty. The risk of premature death is not as previously thought twice as high in smokers as in non-smokers but three times as high. Passive smoking too has been shown to have a whole range of negative effects on health For Example, the development of cancer Mackenbach [24] ischemic heart disease and nicotine dependence.

It's not easy to eliminate Siddiqui [25] T.B from the country within few years because T.B is a communicable disease and it needs a lot of affective. Most T.B cases $-90 \%$ in 2016 Katherine [26] were in adults and almost two-thirds were accounted for by seven countries India Indonesia China Philippines, Pakistan, South Africa, and Nigeria. 6.3 million new cases of tuberculosis reported globally in 2016 represented only $61 \%$ of the estimated incidence only one in five of the estimated number of people with drugresistant tuberculosis was enrolled in treatment. Pipelines for new 
diagnostics drugs and vaccines are progressing but slowly. Actions needed to accelerate progress towards global milestones and targets for Katherine [26] reductions in the burden of tuberculosis disease [27].

Vitamin A deficiency is A Siddiqui [28] a major contributor to child mortality. Vitamin A is a fat-soluble micronutrient Joaquín [29] and are involved in a wide range of physiological processes such as embryonic development vision immunity and cellular differentiation and proliferation. Retinoic acid -RA is the main active form of vitamin $A$ and multiple genes respond to RA signaling through transcriptional and non-transcriptional mechanisms. Vitamin A deficiency -VAD is a remarkable public health problem. An adequate vitamin $\mathrm{A}$ intake is required in early lung development alveolar formation tissue Joaquín [29] maintenance and regeneration [30-35]

\section{CONCLUSION}

This Article teaches us the lesson that Technology in Medical Sciences and Inventions, Discovery of new Medicines and Surgical Instruments are Blessings for Mankind. Latest Technologies such as MRI Scans, CT Scans, Chemotherapy, Radiotherapy, Nuclear Technology, X rays/ Ultrasound, Latest Laparoscopic surgery, Endoscopy, Angioplasty others are treating more ill patients than ever before. But more Medical research is needed to find the Treatment for COVID-19 Pandemic, Ebola, MERS, Avian Influenza, Swine Flu and other Viral diseases. Urgent research institutes needed to build up for the discovery of new Vaccines when needed in times of COVID-19 Pandemic.

\section{REFERENCES}

1. Serap Y, Serhat Ü (2020) Antiviral treatment of COVID-19. Turkish Journal of Medical Sciences 50(SI-1): 611-619.

2. Ahsan AS (2020) The epidemiology of COVID-19 novel corona virus to possibly control the disease and other factors relating to health around the world. Open Acc J Bio Sci 2(2): 330-337.

3. Jeroen C, Peter V (2020) Chloroquine as a possible treatment for COVID-19. Nederlands Tijdschr Geneeskd 164: D4936.

4. Ahsan AS (2020) True or not? Chinese government quotes WHO Chief statement "that there is no evidence that the new coronavirus novel COVID 19 was produced in the laboratory" But US Government Says, "that the coronavirus originated from a laboratory in China despite the lack of evidence". Biomed J Sci \& Tech Res 27(5).

5. Reena P, Ali J, Ahsan Ali S, Nasir M (2018) Febrile neutropenia in patients receiving chemotherapy; an observational study highlighting its association with hematological parameters on gender basis. Cancer Sci Res Open Access 5(1): 1-5.

6. Klaassen D, Shelley W, Starreveld A, Kirk M (1988) Early stage ovarian cancer: a randomized clinical trial comparing whole abdominal radiotherapy, melphalan, and intraperitoneal chromic phosphate: a national cancer institute of Canada clinical trials group report. Journal of Clinical Oncology 6(8): 1254-1263.

7. Hamidah H, Amani TM, Aamir JK, Saira K (2019) BMC Health Services Research 19(1): 690

8. Anwar A, Fatima S, Zia MK, Sohaib T, Ahsan AS, et al. (2018) Sleep apnea in hypertensive patients: relationship with duration of hypertension and the effect of age. Palliat Med Care 5(4): 1-4.

9. Anwar A, Natasha M, Imtiaz M, Razia A, Zarghoona W, et al. (2019) Neurological symptoms in hypertension: Association with blood pressure levels. SOJ Neurology 6(4): 1-6.
10. Jamali Z, Siddiqui AA, Jamali D, Nazim S (2018) Correlation of early and late cord clamping time with hematological variables: An observation study focusing on the neonatal outcomes. SOJ Gynecol Obstet Womens Health 4(1): 1-5.

11. Amna MB, Ahsan AS, Shahzain H, Mir A (2018) Characteristics of chronic myeloid leukemia: an observational study highlighting the correlation of age with hematological parameters. Cancer Sci Res Open Access 5(1): $1-4$.

12. Bradley Chereda, Junia Melo (2015) Natural Course and Biology of CML. Annals of Hematology 94 Suppl 2: S107-21.

13. Reena K, Ahsan AS, Khurram Z, Zubair T (2018) Correlation of duration of chemotherapy with electrolytes in cancer patients: a prospective study assessing the relationship with various electrolytes. Cancer Sci Res Open Access 5(2): 1-4.

14. Bryan O, Scott C, Arnold O (2017) Electrolyte disorders with platinumbased chemotherapy: mechanisms, manifestations and management. Cancer chemotherapy and Pharmacology 80(5): 895-907.

15. IBM (2006) IBM SPSS Software USA.

16. Ahsan AS (2018) The global threat of bird (avian) flu its treatment methods and public health preventive measures. SOJ Vet Sci 4(3): 1-4.

17. Ahsan S (2018) How to efficiently reduce the incidence of tuberculosis (TB) disease in adults in Karachi Pakistan. Journal of American Academic Research 6(3): 45-49.

18. Kasi V, Elango N, Ananth S, Vembhu B (2018) Occupational exposure to photocopiers and their toners cause genotoxicity. Human and Experimental Toxicology 37(2): 205-217.

19. Adetunji H, Pinto LM, Siddique A, Samuel S (2009) Potential occupational health risk from exposure to nano-scale particles from photocopiers: A pilot study. Revue Internationale sur l'Ingénierie des Risques Industriels 2(1): $15-27$

20. Momin A, wajid Z, Adil M, Haleem F, Siddiqui A (2019) Correlation of temperature with platelet count and total leukocyte count in dengue: findings from a secondary data analysis. SOJ Microbiol Infect Dis 6(1):1-

21. Chmielewski P, Strzelec B (2018) Elevated leukocyte count as a harbinger of systemic inflammation, disease progression, and poor prognosis: A Review. Folia Morphologica (Warsz) 77(2):171-178.

22. Jamali Z, Fatima M, Yaqoob S, Ahsan S (2018) Neonatal outcomes in cord clamping: An observational study highlighting the correlation of cord clamping time with hematological parameters. SOJ Gynecol Obstet Womens Health 4(1): 1-5.

23. Adnan A, Hafsa K, Ahsan AS, Summaiya I, Zarghoona W, et al. (2018) Prevalence of clinical signs and symptoms of hypertension: a gender and age-based comparison. Palliative Med Care 5(2): 1-8

24. Mackenbach JP, Damhuis R, Been J (2017) The effects of smoking on health: Growth of knowledge reveals even grimmer picture. Ned Tijdschr Geneeskd 160: D869.

25. A Siddiqui (2018) Tuberculosis in adults in Pakistan: Its epidemiology, preventive measures and current legislation. Journal of American Academic Research. 6(3): 33-38.

26. Katherine F, Philippe G, Alimuddin Z, Mario R (2018) The global tuberculosis epidemic and progress in care, prevention, and research: an overview in year 3 of the end TB era. The Lancet, Respiratory Medicine 6(4): 299-314.

27. Google images (2020) covid antiviral drug images.

28. Siddiqui A (2018) Critically review and evaluate national tuberculosis control program (NTP) of Pakistan. Journal of American Academic Research 6(3): 28-32.

29. Joaquín T, Lucía RF, Rosa Z, Marín M (2018) Vitamin A deficiency and the lung. Nutrients Journal 10(9): 1132. 
30. Amna MB, Siddiqui AA, Wajid Z (2018) Presentations in patients of chronic myeloid leukemia; an observational study focusing on the association of haematological parameter on gender. Cancer Sci Res Open Access 5(1): 1-5

31. Reena K, Ali SA, Zubair T, Fatima S, (2018) Levels of electrolyte in cancer patients; a prospective study focusing on the variations before and after therapy. Palliat Med Care 5(4): 1-4.

32. Reena K, Ahsan Ali S, Shahzain H (2018) Chemotherapy in different cancers; an observational study highlighting the association of febrile neutropenia with various hematological parameters. Palliat Med Care 5(3): $1-4$

33. Siddiqui A (2018) Strategies for the prevention and elimination of vitamin A deficiency. Journal of American Academic Research 6(3): 3944.

34. Google images (2020) Avian Flu Virus.

35. Ali HK (2017) Tuberculosis control in sindh, pakistan: critical analysis of its implementation. Journal of Infection and Public Health 10(1): 1-7. 